logos_i_ethos_2021_1_(56), s. 29-50

DOI: http://dx.doi.org/10.15633/lie.3937

Maciej Manikowski

https://orcid.org/0000-0002-8278-5475

Uniwersytet Wrocławski

\title{
The Other as Another. In the Footsteps of Józef Tischner's Philosophy of Dialogue
}

\begin{abstract}
During the Conference Oblicza obcości w filozofii i literaturze (The Alien in Philosophy and Literature) held in Poznań in March 2016, Piotr Domeracki said: "It is a truism - albeit one that must be pointed out Maciej Manikowski, born 1966, philosopher and theologian, professor of philosophy since 2016, specialist in philosophy of dialogue, philosophy of religion, philosophical anthropology and philosophical mystics.
\end{abstract}

in the context of what we are discussing - to say that the issue of The Other has become one of the fundamental - if not exponential - problems of philosophy, especially contemporary philosophy, sensitive to ethics or displaying ethical inclinations. This is not to say, however, that such has always been the case." Soon enough, history wrote another page. First, the unprecedented influx of immigrants, mainly from Africa, into Europe (or a few Western European countries, to be more exact), and the related major crisis of anthropological thought with various attempts at coming to terms with this other; followed by an even more serious crisis in the form of the global coronavirus pandemic and the Covid-19 disease which redefined our thinking about the other. Suffice it to mention the protests against restrictions, where selfish interests outweighed one's concern for

1 P. Domeracki, Heterologia. Od stygmatyzacji do gloryfikacji Innego w filozofii, in: Oblicza obcości, red. M. Jedliński, K. Witczak, Bydgoszcz 2016, p. 73. 
others, or the ever more effective ways of cheating on the authorities, where, again, another man became a means rather than an end, contradicting the idea proposed by Immanuel Kant.

These two situations - and there are, of course, many more - show that what is important for philosophy, especially modern philosophy, is so only on the theoretical plane, as it does not, or perhaps cannot, translate into practice or everyday human life. Such situations, neither new nor last, seem to contribute to a new way of looking at other people, especially when they are - for various reasons - another, or are perceived as such. One must ask a fundamental question, the one I am asking myself here: what makes another remain another, and what makes another become the other for us? Where is the source of such an attitude? Many philosophers, as aptly discussed by Domeracki, have struggled with this issue. In the Polish philosophical thought, an immense space for analysis has been created by the philosophy of dialogue and the philosophy of encounter.

Following in the footsteps of Józef Tischner's dialogical thought, I would like to retrace one possible path on which another becomes the other. Since to goal is to follow in the philosopher's footsteps, this text cannot be regarded either as a comprehensive presentation of Tischner's philosophy of another, or as an attempt at its interpretation; for not all following is interpretation, it may simply be an inspiration. As Tischner himself said: "In my work ... there is a very clear direction leading towards man, but I like to challenge, to question what might appear self-evident. I know this may sometimes be destructive, but my point is to expose the emptiness of the common way of thinking, common way of speaking, to show that you cannot stop, that there is something more, something deeper." Such an approach is a source of inspiration, an attempt at seeing what lies beneath our everyday attitudes and judgments; for it seems that this stereotypical approach to another continues to dominate, especially

2 Oby wszyscy tak milczeli o Bogu! Z ks. Józefem Tischnerem rozmawia Anna Karoń-Ostrowska, Kraków 2015, p. 173. This assertion is, in a way, a comment on differences in the attitudes of Karol Wojtyła and Józef Tischner. 
in journalism or the media which determine the opinions we speak out every day. So why is another still another, and why doesn't he become the other?

\section{The Constitution of Another}

Where did the crisis come from in our looking at the other as another? How has the other man (suddenly?) become another? Referring to the heritage of Joseph Tischner's phenomenological thought, one likely conclusion could be that it stems from modern philosophy, or in fact from what might be called the epistemological paradigm of doing philosophy. Speaking of a crisis here, I would like to point out that every crisis can be thought of at least in two ways: negatively and positively. It is negative when a crisis situation leads to a decline of thinking or even to a rejection of thinking, or to concluding that we have not been thinking as yet; it is positive when, despite the crisis situation, we find a way out, and our thinking, already following in new tracks, keeps on going (instructed by the crisis). What I have in mind when speaking of modern philosophy as a crisis of thinking about the other is the positive aspect, because it has prompted the emergence of many new ways of doing philosophy, in which there is room for the other; or better: for another as the other. And this juggling of terms, one time "another," another time "the other," shows a situation of indecision: are we already speaking of another as the other, or still about another as another?

Unlike the ontological paradigm, the epistemological paradigm of philosophy, usually reconstructed based on the writings of Descartes, does not focus on an existing being, but on the way it is known, because the former, referring to an objectively existing reality, presupposes its knowability, which has turned out to be questionable. So instead of the fundamental (ontological or metaphysical) question What is?, a more "primary" question is asked: What can I know?, which clearly locates the point of departure in the knowing subject and not 
in the reality that is being known. ${ }^{3}$ This, naturally, must have consequences, both positive and negative ones, also for our thinking about another person.

The first consequence is a radical distinction between the subject and the object; radical, because referring to the roots (radix - root) of the theory of knowledge. The one who knows is the knowing subject; that which is known is the object of knowledge. This approach leads first towards the subject (internalization) and only later towards the object, as can be clearly seen in the Kantian version of the main philosophical question: what are the conditions for the possibility of knowing an object. Naturally, also in the ontological paradigm we spoke of knowing an object, we also distinguished between the subject and the object, but while in ontological thought the starting point is the object, an existing being, in the epistemological paradigm it is the knowing subject, which is why it is also called the awareness or the mental paradigm. ${ }^{4}$ The other consequence arises from the first one and is, in a sense, the answer to the question: How does this apply to knowing (another) man? For the knowing subject, another man is an object, for he may be nothing but an object of knowledge, thus losing that which is his essence - being a man, being a subject; this way becoming another, that is, other than me, object of my knowledge. And while at the very beginning of modern philosophy the danger of this objectification of man could not be discerned yet, at the end of the period customarily called modernity it could already be seen most explicitly. This way, the other (man) was constituted as yet another object of knowledge, and therefore - consequently - as another in general. ${ }^{5}$ This was how Martin Buber, among others, saw this when he formulated the principles of dialogical thinking; this was how Joseph

3 This is a useful shortcut which helps put forward a certain fundamental thesis, necessary to show the crisis that comes with the modern way of looking at the other.

${ }^{4}$ Cf. H. Schnädelbach, Filozofia, in: Filozofia. Podstawowe pytania, red. E. Martens, H. Schnädelbach, przeł. K. Krzemieniowa, Warszawa 1995, p. 66-89 (original title: Philosophie. Ein Grundkurs, Hamburg 1985).

${ }^{5}$ If someone notices a major mental shortcut here, it is intentional, because that is the only way to make the other another - by reifying him, which I will come back to further on. 
Tischner thought about it when building his philosophy of drama; and so would many other philosophers think who espouse the tradition of the philosophy of dialogue.

\section{Primal Distance and Entering Into Relation}

One might say that in his philosophical reflection on man, Martin Buber considers how this reifying tendency in our thinking could be reversed. In his classic works in the philosophy of dialogue, he shows two planes witch - coupled with each other - may provide a springboard from which to look at the other from a new, different perspective. He calls them primal distance and relation.

What is the former of the two? Buber writes that "the principle of human life is not simple but twofold, being built up in a twofold movement that is as such, one movement as the presupposition of the other. I propose to call the first movement 'the primal setting at a distance' [Urdistanz], and the second 'entering into relation' [In-Beziehungtreten]. That the first movement is the presupposition of the other is plain from the fact that one can enter into relation only with a being that has been set at a distance or, more precisely, has become an independent opposite. And it is only for man that an independent opposite exists." ${ }^{\text {Th }}$ This primal setting at a distance, or distancing oneself (Germ. Verfremdung - which includes the word Fremd, or strange), results in that something becomes - firstly - an independent opposite, and therefore also - secondly - an independent opposite vis-à-vis me, rather than merely some more or less important element of the space or world around me. Tischner would say at this point that something ceases to be only an element of the stage (I will come back to this later on). And this means that it has somehow been singled out, marked, isolated. As noted by Piotr Paweł Repczyński: "The primal setting at a distance is a movement of consciousness that consists in moving the Self away from something that is not the Self. 
It separates me from that which is without rather than within me. This way we develop self-awareness and build our own identity."

The primal setting at a distance does not change anything in the environment, in the objectively existing world; it causes a change in the subject himself. This movement makes - though not in a physical sense - the space around me expand, become more transparent, which allows me to see differently. It must be emphasized that this plane causes changes only in the one who knows, the one who encounters another, and not in the world or in that other. But, as we will see in a moment, a movement that makes a change in me also makes a change in another, because the distance is in a way bilateral. This change appears already at the first encounter of another, though it may arrive in our consciousness with some delay. This is beautifully illustrated by a scene in Iris Murdoch's novel The Green Knight. At the end of the novel, when everything has already been solved, when all the threads have been straightened out, in recalling what happened Louise Andreson describes the first meeting with Peter Mir, one of the key characters in the story: "We saw him from the window, out in the rain with his umbrella, and didn't know who he was, and we were

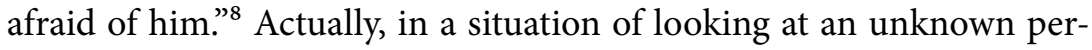
son, anyone could say the same, which would be neither revealing nor strange. From the story itself, we know that this look at Peter Mira was a look from the window, making the space between Louise Anderson looking from above and Peter Mir standing below expand - though not physically - as he became for her an independent opposite, to use Buber's expression. And although in the beginning, at first glance, as Anderson recollects, she was convinced that he was a stranger, because she did not know him, and was afraid of him; after a while she realized that he was not, that he was becoming the other, that she was beginning to enter into a relationship with him, and one of the first ones was when Peter Mira

7 P. P. Repczyński, Obcy jako drugi w filozofii dialogu i spotkania, in: Oblicza obcości, op. cit., p. 42. Por. M. Manikowski, Warunki możliwości spotkania innego jako drugiego: Martin Buber i Józef Tischner, in: Oblicza obcości, op. cit., p. 63-64.

8 I. Murdoch, The Green Knight, Penguin Books 1995, p. 360. 
physically stood at the door of her apartment and rang the bell. What is this entering into relation?

It is the second movement, related to the first one, that of primal setting at a distance. Martin Buber writes: "Now the second movement has been added to the first: Man turns to the withdrawn structure of being and enters into relation with it. (...) it is not possible to think of an existence facing a world that is not (...) the outline of an attitude of relation; that is, no more than that an animal does not know the state of relation because one cannot stand in a relation to something that is not perceived as contrasted and existing for itself."' The primal setting at a distance is not only the contrasting and discovery of something that is (becomes) an independent opposite, but also what makes us see this thing precisely as existing for itself, and being an independent opposite vis-à-vis myself. Only the contrasting is able to accomplish this, as it changes one's perspective (our eyes are no longer restrained, so to say), and then I can see that this contrasted thing is precisely something independent and opposite vis-à-vis myself. This allows me to enter into relation, because I can only interact with what is contrasted, separated and stands as independent in itself opposite myself. As Repczynski points out, "the primal setting at a distance, as the first movement of consciousness, is necessary to perceive, to observe what is not mine, what is not me, what is alien." ${ }^{10}$ Entering into relation leads to a situation of dialogue, encounter, or rejection. Looking for the first time from the perspective of her own window, Louise Anderson from Iris Murdoch's novel made this primal distancing movement by which she singled out Peter Mira, who became for her an independent opposite; and then looking at him any other day, or finally seeing him at her door, entered into a relationship with him, truly encountered him; and it was possible, because the primal setting at a distance allowed her to see him in the first place. He became for her a Thou, just as she became a Thou for him, and it was possible only

9 The Martin Buber Reader, op. cit., p. 207.

10 P. P. Repczyński, Obcy jako drugi..., op. cit., p. 42. 
because they entered into relation with each other - she with him and he with her.

\section{The Intentional and Dialogical Plane}

When reading Joseph Tischner's texts, we find very similar analyses, even though, surprisingly, he refers to Martin Buber's writings very rarely, or almost not at all; indeed, his thought is closer - probably through the phenomenological, anthropological and ethical tradition - to that of Emanuel Lévinas. And because it stems from an entirely different philosophy, his approach is different too, leading to slightly different conclusions. The two planes referred to in the subtitle - intentional and dialogical - arise from a certain way of looking at man and the world. On the one hand, man lives in a world that is completely independent of him - it is a world of things around him, although we should say that the stage is all that a person is not (in modern terminology - knowing man as the subject). Already on the initial pages of his main work implementing a novel philosophical idea we read: "We're in the world as on a stage. Our attitude to the stage may change as the drama develops, and may vary depending on the types of objects that fill the stage. But that which is essential does not change. What is essential? The open possibility of objectification. Objectification may affect, piece by piece, the entire world." ${ }^{11}$ All that is around me is a stage where there is me and other things; I as an actor, as Shakespeare wrote, and everything else as props. ${ }^{12}$ I am aware of this, aware of the stage, because I am led to this awareness by my knowledge, which by its very nature is intentionally oriented towards the object (the object of knowledge).

The situation changes, however, as I start to think about another person who appears on the stage. How do I talk about him? What should I do with him? Reflecting on this, Tischner says about Husserl and

11 J. Tischner, Filozofia dramatu. Wprowadzenie, Kraków 1999, p. 13.

12 Cf. W. Shakespeare, As You Like It, Act II, Scene VII, https://shakespeare.folger.edu/download/ (15.04.2021), vers. 144-145. 
Heidegger that "both of them really talk about man's relationship to the stage. The issue of the man-to-man relationship escapes them, so if they talk about it at all, they do so in a stage-like way, turning man into an object, a being." ${ }^{13}$ In a sense, Tischner is being lenient on his two philosophical masters, for he knows that they do not know how to speak a language other than that of the stage, in which man is simply objectified, turned into a being, one of the many other beings of the stage. They lack a perspective that is different from the intentional approach; they lack a perspective in which they would realize the existence of another person precisely as the other, and not as yet another thing in their surroundings. In his thought, Tischner calls it a dialogical opening. ${ }^{14}$ However, before I discuss this opening, as with Buber's primal setting of a distance and entering into relation, it is necessary to realize the primary nature of yet another opening - the intentional one.

What is an intentional opening, or plane? "The plane of intentionality is the plane of actual or potential 'reifications,' 'objectifications' - horses, dogs, trees." ${ }^{15}$ It is, therefore, a movement of our consciousness, to stick to the term, where we treat what we see around us as objects or things. "What is an object? We say: that which is objective. What does 'objective' mean? It means that it is given not only to me, not only to you, but also to us, to many like us. Intentionality 'reifies' and 'objectifies' in order to make things more easily available to every possible subject." ${ }^{16}$ Intentionality is not bad; it is natural, this is how our cognition works, because in order to make available what is known to many, it must become objectified, or reified. The problem arises when another person appears on the horizon of our cognition. Because on the one hand we may treat him as another object in our surroundings, as Edmund Husserl does in his Ideas when he talks about apperceiving "the material Corporeal body,"17

13 J. Tischner, Filozofia dramatu, op. cit., p. 14.

14 Cf. J. Tischner, Filozofia dramatu, op. cit., p. 17.

15 J. Tischner, Inny. Eseje o spotkaniu, Kraków 2017, p. 8.

16 J. Tischner, Inny, op. cit., p. 11.

17 E. Husserl, Ideas Pertaining to a Pure Phenomenology and to a Phenomenological Philosophy: Second Book, translated by R. Rojcewicz and A. Schuwer, Springer 1990, Section Two, §43, p. 162. 
and, on the other hand, we may see in him another subject, and then the intentional approach is not enough. "Another," Tischner writes, "is not yet another thing among other things or object among other objects, but a subject, another I, one who becomes for me a Thou or a He, and with whom I may enter into the community of Us." ${ }^{18}$ But I can see this only when I transcend the intentional plane and enter the dialogical plane. What is the starting point of this transcendence? Seeing in another person another Self. "Another - another I, another subject of consciousness - is 'open to that which is other': the world, people in the world, God. His opening, like mine, is dialogical and intentional. A dialogical opening means that we can be for each other - he for me and I for him I, Thou or He. (...) The dialogical opening 'personifies', the intentional opening 'objectifies."' ${ }^{19}$ Dialogical opening is possible because, quite simply, I see in another a Self, another person, and not merely another object; that I see in him the same opening that I experience in myself. And secondly, I discover, and not only realize, that a dialogical opening happens - due to the very nature of dialogue - dia logos, through word, that is, in speech.

\section{The Constitution of Another}

Unlike Martin Buber, Tischner points out that entering into a relationship is only possible in the case of persons, and therefore it is not possible to enter into a relationship with animals or the world of nature. And this is due to what I have already mentioned, the fact that a dialogical opening is possible through the word, but also - as we will see by a certain way of going out which is possible only in the case of man.

The Krakow philosopher shows - firstly - that another is one I can converse with: “The words 'I,' 'Thou', 'He,' 'We' are integral parts of speech. Another is, after all, the one I can talk to" ${ }^{20}$. In the understanding

18 J. Tischner, Inny, op. cit., p. 8.

19 J. Tischner, Inny, op. cit., p. 9.

20 J. Tischner, Inny, op. cit., p. 8. 
of speech and talk, the difference between intentional and dialogical opening can be seen once again, in this case reflected in the difference between "what is being spoken of" and "who is being spoken to." In continuation of what he had said earlier, Tischner adds: "There is a difference between who I can talk to and with, and what I can talk about. Who I can speak to and with is in the dialogical dimension of consciousness, and what I can talk about fills the intentional dimension." ${ }^{21}$ It is, in a sense, obvious that what I can talk about belongs to the world of things, and so it appears to me in the intentional opening, and who I can speak to and with belongs to the world of the other, and therefore is revealed only in a dialogical opening. It is worth noting here that these two openings are a very good description of man's approach to God. On the one hand, there is "speaking of God," that is, treating God as "the object of our interest." This would be the area of the philosophy of God, often called onto-theo-logy, or speculative theology. On the other hand, there is "speaking to God" or "speaking with God," which shows that we "treat" God not as an object, but as a person, because we can only speak with a person or to person. However, this distinction between "talking about" and "talking to" is supplemented by Tischner, probably due to the legacy of phenomenology again, as well as Heidegger and Lévinas, with yet another distinction - between "talking about" and "talking at."

Before I present this view of dialogical opening, one important remark needs to be made about the former of these terms as used by the author of the Filozofia dramatu (Philosophy of Drama). Talking about in its first philosophical sense is not anthropological, but ontological, because it concerns the world of things and the way of talking about these things that means discussing them, as in everyday life we are speak of "discussing a particular matter" or "discussing a particular issue," but also: "discussing a man," which would immediately suggest his objectification. And this should not be the case, because "talking about" comes from the realm of intentionality, while "talking at" comes from the sphere of dialogue, which makes them stand in opposition to each

${ }^{21}$ J. Tischner, Inny, op. cit., p. 8. 
other: "Less important to us at the moment is what the word is (the intent); it is important that the word is addressed to another (the dialogic). The intentional aspect of speech is talking about, the dialogical aspect of speech is talking at." ${ }^{22}$ This distinction illustrates the specific nature of what the author calls "talking at," as it does not refer to a situation of flooding others with words without letting them say anything or giving them a respite.

Continuing along the lines of this distinction, Tischner points to an aspect of dialogue that proves essential in the entire concept of encounter or drama. A few lines further on we find an important paragraph referring to Theunissen's work: "In the order of speech, there is a consistent dichotomization of talking to and talking about. 'Thou' is always and essentially the one who is being talked to or invited into the conversation, whether it is another (me talking to someone), or myself (me being talked to). This is the case not only in Buber, but in the entire philosophy of dialogue." ${ }^{23}$ Talking at is thus possible only in the space of dialogue, for when a word is addressed "at" it is not a word "about" man, and consequently the one being "talked at" is singled out from among the things on stage, treated personally; he is, in a sense, "de-reified," "de-objectified," and this creates a community. ${ }^{24}$ Even though Tischner makes it clear that this talking at is actually bi-directional, as it depends on the one who is talking, the question that needs to be asked is this: "Where is the source of this talking at? Who, in the essential sense, is talking?

The issues described here, both those taken from philosophical thought and those from literature, might suggest that the initiative is always on the side of the one who, in Buber's terms, sets a primal distance and enters into relation or, in Tischner's terms, performs a dialogical opening and starts talking. A more careful reflection reveals, however, that it is the other, the one who is standing vis-à-vis me, who is the source

22 J. Tischner, Inny, op. cit., p. 52.

${ }^{23}$ J. Tischner, Inny, op. cit., p. 53. Tischner refers here to Michael Theunissen's Der Andere (Berlin-New York 1977, p. 282).

${ }^{24}$ Cf. J. Tischner, Inny, op. cit., p. 59. 
of dialogue, encounter, or talking at. For even if I am the first to talk at the other, I am talking at the other because he has appeared to me as the other, rather than being yet another object (prop) on the stage. Why? Because the talking at should not only be considered in terms of spoken words. Another person may be talked at in a variety of ways. For example, it may happen the way it did to Moses whom God talked at in the burning bush; or we may be talked at by discovering a deeper meaning in the daily "Hello!:" or it may happen the way it did in Iris Murdoch's novel when Peter Mir talked at Louise Anderson through his "standing out in the rain with his umbrella." It may be helpful here to refer to Buber's distinction between "calling out" to someone and "addressing" them. Buber explains it as follows: "Men express themselves to men in a way that is different, not in kind or degree but essentially, from the way animals express themselves to their companions. Man and many animals have this in common, that they call out to others [Anrufen]; to speak to others [Anreden] is something essentially human and is based on the establishment and acknowledgement of the independent otherness of the other with whom one fosters relation, addressing and being addressed on this very basis." ${ }^{25}$

This may be explained using a simple example. A dog who starts barking in the country does not address his barking to any particular other dog, but is barking "in general" and so his barking is only a calling out. It is answered by a dog, but not any particular one, because it did not address his barking to any particular dog. If a man ever calls out at all, he generally calls out by name, "Paul!" or "John!," which is not only calling out, but also addressing, as it is directed towards a particular person, not any man at all. If we look at Peter Mira from Murdoch's novel, "standing out in the rain with his umbrella," we realize that his standing there is not just calling out, it is addressing, because it is directed to a particular person, in this case - a resident of the tenement house across the street. And one more thing that will be important in just a moment - talking at demands attention. It may consist in directing

25 The Martin Buber Reader, op. cit., p. 210. 
our gaze towards the person talking, or in answering the question he is asking, or even in escape (whether by retreating into silence or by physically running away): "Addressing is a barging-in invitation that calls for reciprocity. By embarking upon the issue of addressing, we enter the great expanse of reciprocity and its conditions." ${ }^{26}$ In order to enter into reciprocity, one needs to be a person and understand entering into relation.

\section{Person and Relation}

One word or term that has often appeared in these analyses is "person." I will begin my introduction to the concept of person by describing encounter, because I believe this is where we can find a slightly different understanding of person than is usually found in philosophy or theology. ${ }^{27}$ The most interesting and inspiring attempt at characterizing encounter is that proposed by Jerzy Bukowski, very firmly rooted in the philosophy of dialogue or philosophy of drama. "An encounter is a sudden, non-reducible, reciprocal, emotional, non-discursive, direct opening of two persons towards each other; they feel a connection to each other manifested in a sense of the other person's irreplaceability and an axiological and moral 'self-transcendence' in the face of the mystery of the Absolute." ${ }^{28}$ Bukowski arrives at this "attempt at a definition" via many routes, by analyzing philosophy, especially modern philosophy, by drawing attention to "cogito ties," but also by analyzing literary works or situations from everyday life. He is simply trying to approximate what he calls encounter, to lead us towards that understanding rather than precisely explain something. Therefore, his description takes on the form of listing some features which are essential to what we call an encounter. The subsequent pages of his book present his attempts at further explaining these features. For my part, I would like to draw attention

26 J. Tischner, Inny, op. cit., p. 53.

27 I am, of course, referring to the concept of person proposed by Boethius.

28 J. Bukowski, Zarys filozofii spotkania, Kraków 1987, p. 154. 
to three of them, because they lead, as I mentioned above, to a different understanding of person.

An encounter is mutual, it is a meeting of two equal subjects (though not in the sense of modern philosophy), two equal persons; ${ }^{29}$ there are no, for there cannot be any, fundamental differences between them (there are only accidental ones). An encounter is an opening of two persons towards each other, and it is - as we already know - a dialogical opening, not just an intentional one. An encounter is what reveals to us the irreplaceability of the other person. On the one hand, it may be said that this is, in a sense, a structural irreplaceability, since without the other there is no encounter (an encounter with oneself is not a complete encounter) and, on the other hand, as I will explain further on, that irreplaceability concerns not only the encounter itself, but the personhood itself. The fact that the encounter is circular, that it is a dialogical circle, shows the mutual conditioning of being a person and entering into a relationship (encounter). Only persons may meet, encounter is only proper to persons. So what does it mean to be a person in this context? Józef Tischner explains this in his Filozofia dramatu when he writes that by meeting another human being and entering into relation with him by addressing him, I discover that "You - a Thou for me - are the I for yourself, and so I, who am the I for myself - I am a Thou for you. This knowledge provides an abutment from which you can build a bridge between I and Thou."30 Or, as Shakespeare would poetically put it, "Thou are me, and I am Thou."31 There are three consequences of such a view of the encounter between I and Thou.

29 I am referring here first of all to the philosophy of Martin Buber and Józef Tischner, of course, and not that of all dialogists, who sometimes make suggestions of an asymmetrical encounter. One example is the encounter with God in Bukowski (although he also shows equality, because both God and man are persons, even though they are ontologically different) or the encounter with Thou in Lévinas. Cf. J. Bukowski, Zarys filozofii spotkania, op. cit., p. 221-239; E. Lévinas, Totality and Infinity: An Essay on Exteriority, Springer 2011.

30 J. Tischner, Filozofia dramatu, op. cit., p. 111.

31 Cf. W. Shakespeare, Romeo and Juliet, Penguin Books 1994, Act II, Scene II, p. 56-65. 
Firstly, this mutual opening towards each other eliminates the conclusion of Leibniz's thinking that we are only "monads without windows or doors." ${ }^{2}$ If I see in the other another I, who, for himself being the I, is at the same time a Thou for me, and, similarly, recognizing that I am the I for myself, but a Thou for the other, I cease to be merely a monad (a monologic being), and become a dialogic being instead. Secondly, this bridge built between I and Thou, supported by the abutment which is both I and Thou, shows a different situation from the engineering point of view, for it is a bridge built from both abutments simultaneously - from I towards Thou, and from Thou in the direction of I. And thirdly, the most important thing is that building a bridge starts because I have perceived a Thou, and in this Thou I perceived "a Thou for me" and "the I for yourself," which means: each subject is both an I and a Thou. What does this mean for being a person? It seems that this may only be read in hermeneutic terms from Tischner's description.

In 1998, Jan Choroszy published a composite work under the very surprising title Człowiekiem się rodzę, osoba się staję (I Am Born a Man, I Become a Person)..$^{33}$ One could point not only to an anthropological, but also to a philosophical or theological inaccuracy here, for even in Christian-oriented anthropology it is assumed that one is a person from birth (from conception) and not as a result of some process. However, it seems that reading this title in the broader context of dialogical thought reveals something meaningful. I become a person only when I open myself to another, when I go out towards another, and not when I withdraw into myself, like the Leibnizian monad "without windows or doors." This very significant quote about the reciprocal construction of a bridge shows that being a person happens in motion, in a twofold movement - directed towards the other in whom we discover his

32 G. W. Leibniz, The Monadology, CreateSpace Independent Publishing Platform 2015, § 7; cf. J. Tischner, Filozofia dramatu, op. cit., p. 89.

33 J. F. Choroszy, Człowiekiem się rodzę, osoba się staję, Oleśnica 1998. The book contains term papers by Philosophical Anthropology students at Wrocław University's Institute of Philosophy. 
"Thou for me" and at the same time his "I for myself", and the other way round, when I discover my being "the I for myself" and "a Thou for the other." Both movements are simultaneous, but only because in my dialogical opening the other could appear as the other. If that were not the case, I would not be a person, and so Choroszy rightly says that one is born a man (an object in the intentional opening) and becomes a person (a subject in the dialogical opening). To use wellknown philosophical terms, one can say: a person is a hypostasis, that is, a specific, concrete, individual being, and an ecstasy, that is, a being going out towards the other. ${ }^{34}$

From this being a person arises the natural - because inherent in our nature - entering into relations. From this being a person stems the dialogical opening towards the other. It also follows that I cannot treat another as a stranger; for I cannot enter into a relation with someone I consider a stranger, that is, someone who is not a Thou to me, and therefore not an I to himself, and so who simply does not appear on my horizon at all. There is no place where such a non-encounter could occur. After all, encounters happen in their own proper places. I can encounter another at home, in my house or in his house, where the other in the essential sense are my loved ones or his loved ones. I can encounter another person at the workplace, at the office or at school, but here I encounter others only temporarily, only when I am with them at work. I can encounter the other in the temple, meet him as a co-participant in the liturgy, though perhaps I encounter him rather as a monological person at prayer. I can encounter the other in the cemetery, but here I encounter him in memory rather than physically. Is there another place where I encounter the other, and encounter him most often? Yes, there is - on the road.

\footnotetext{
34 This is due, I think, to the relational (dialogical) account of the Holy Trinity. Cf. M. Manikowski, Relacja i dialog. Wprowadzenie do ontologii trynitarnej, Wrocław 2018.
} 


\section{The Road Where we Encounter Another as The Other}

When we ask about a place where we can encounter another person, we are nevertheless asking about a stage we know or want to know very little about, because when dealing with man the philosophers of dialogue have often treated the stage, that is, the world, with some neglect. Dobrosław Kot writes: "In Tischner's philosophy, the main emphasis is on human relationships, on the condition of the subject who encounters Another. The world - understood as a stage for the drama - appears precisely as the stage of human encounters." ${ }^{\text {"W }}$ We usually only talk about the stage when we talk about the drama being played on it, and only then. Even in everyday life we can see that, for example, the Oscar for set design is less appreciated than for the lead acting role or for the best film. All of this shows that we must go a little deeper into dialogical thought in order to find (identify) the most important place where one may encounter another as the other.

Such a place is the road. Perhaps because, as Dobrosław Kot points out in his interpretation of Tischner's proposal, "a road connects houses, workshops, temples and cemeteries." ${ }^{36}$ And also because it is on the road that dramas take place, human dramas and encounters the stage for which is rarely provided by a house, a temple, or a cemetery. But perhaps, first of all, because it is on the road that we most often meet a stranger, another, the other; it is on the road that it is easiest for us to encounter a man. It is the most natural - both in the intentional and in the dialogical sense - place to meet, to come together; the most natural place for our paths, our errings, as Józef Tischner used to say, simply to converge. In this aspect, Kot writes, "the road is a place of meeting

35 D. Kot, Tischnerowska filozofia sceny, „Colloquia Communia” 1-2 (2005) nr 78-79, p. 123. Cf. M. Manikowski, Warunki możliwości spotkania innego jako drugiego, „Colloquia Communia” 1-2 (2005) nr 78-79, p. 68-69.

36 D. Kot, Tischnerowska filozofia sceny, op. cit., p. 131. Looking at Dobrosław Kot's most recent publication, such a place of encountering another as the other may be a raft, a pontoon or the primitive boat of a migrant sailing towards Europe. Cf. D. Kot, Tratwa Odysa. Esej o uchodźcach, Gdańsk 2020. 
strangers. Strangers do not come straight into the house. A stranger is on the road." ${ }^{37}$ In Iris Murdoch's The Green Knight Peter Mir is standing on the road (a street, after all, is a road) in front of Louise Anderson's house, on the road to Louise Anderson's house, and he will only get inside the house when he is invited there, even if at first the reader's impression may be that he has barged in.

The road also points us to yet another special place, one that is also connected with the road, and not only by intentional relations, but dialogical ones as well. It is the inn. It is understood here as an extension of the road. It is a special place. At the inn, there are both strangers and friends, aliens and people we are familiar with. Next to the friends we have been drinking vodka or beer with for years on various occasions, and who are sitting at our table, or at whose table we are sitting, talking to us, arguing about important or trivial matters, there are also others, maybe sitting in a dark corner and interested in their own pint of beer, or maybe only appearing to be sitting on the side, but watching us all the time. They are travelers, strangers, those who find themselves here accidentally, and sometimes even people hostile to us who are here perhaps - on our account. The inn, however, is a space which forces us, in a way, to engage in a dialogue which might not be possible elsewhere, at home, at the workplace, at the temple or in the cemetery ${ }^{38}$ It is in just such an inn that the four Hobbits carrying the ring, sitting at a table, see a Stranger sitting in the corner and looking at them; a Stranger who already at the first contact - visual or verbal - turns out to be known to them, even if only from stories, as Strider, who later on becomes a participant in the Expedition, or a fellow in the Expedition. Their encounter would probably have looked very different if they had found out at the outset that he was Aragorn, son of Arathorn, the heir of Isildur. They might then feel some uneasiness; but as it was, with some concealment, it was easier for them. Since he is a Traveler, just like themselves, this absence of shyness opens them up (dialogically) to the encounter and

37 D. Kot, Tischnerowska filozofia sceny, op. cit., p. 132.

38 Cf. D. Kot, Tischnerowska filozofia sceny, op. cit., p. 132. 
allows them to enter into relation. The inn is therefore a place where an encounter comes most easily and is most natural; for in it everyone is a guest rather than the host, everyone is - in a sense - a stranger, not a fellow. Both the inn and the road are places where our dialogical opening to another person is most naturally revealed, where the situation of setting at a distance and entering into relation is natural, where an intentional opening quickly turns into a dialogical opening, where we become persons, where another appears to us as the other.

\section{Conclusion}

At the beginning of this text, intended as an inspiration, the beginning of a journey, I asked myself two questions: What makes another remain another, and what makes another become the other to us? Where is the source of this attitude? Following along the path of dialogical thought, we discover that the fact that another becomes the other is determined by what is called a dialogical opening, understood as seeing in the other another person (a subject) and not just one of the many elements of the stage, that is, the objective environment. This singling out is at the same time entering into relation with another, in which I constitute myself as a person, and consider him as a person as well. And this happens through dialogue, dia logos, that is, through addressing with a word. The place where this comes most naturally is the road, where it is easiest to encounter another, and the inn, where - as an extension of the road - we are all guests at first, that is, others, where it is easier for us to become - for one another - the other.

\section{Bibliography}

Bukowski J., Zarys filozofii spotkania, Kraków 1987.

Choroszy J. F., Człowiekiem się rodzę, osobq się staję, Oleśnica 1998.

Domeracki P., Heterologia. Od stygmatyzacji do gloryfikacji Innego w filozofii, in: Oblicza obcości, red. M. Jedliński, K. Witczak, Bydgoszcz 2016, p. 3-83. 
Husserl E., Ideas Pertaining to a Pure Phenomenology and to a Phenomenological Philosophy: Second Book, translated by R. Rojcewicz and A. Schuwer, Springer 1990.

Kot D., Tischnerowska filozofia sceny, "Colloquia Communia" 1-2 (2005) nr 78-79, p. 123-132.

Kot D., Tratwa Odysa. Esej o uchodźcach, Gdańsk 2020.

Leibniz G. W., The Monadology, CreateSpace Independent Publishing Platform 2015.

Lévinas E., Totality and Infinity: An Essay on Exteriority, Springer 2011.

Manikowski M., Relacja i dialog. Wprowadzenie do ontologii trynitarnej, Wrocław 2018.

Manikowski M., Warunki możliwości spotkania innego jako drugiego: Martin Buber i Józef Tischner, in: Oblicza obcości, red. M. Jedliński, K. Witczak, Bydgoszcz 2016, p. 61-70.

The Martin Buber Reader. Essential Writings, ed. A. Biemann, Palgrave Macmillan 2002. Murdoch I., The Green Knight, Penguin Books 1995.

Oby wszyscy tak milczeli o Bogu! Z ks. Józefem Tischnerem rozmawia Anna Karoń-Ostrowska, Kraków 2015.

Repczyński P. P., Obcy jako drugi w filozofii dialogu i spotkania, in: Oblicza obcości, red. M. Jedliński, K. Witczak, Bydgoszcz 2016, p. 42-51.

Schnädelbach H., Filozofia, in: Filozofia. Podstawowe pytania, red. E. Martens, H. Schnädelbach, translated by K. Krzemieniowa, Warszawa 1995 (original title: Philosophie. Ein Grundkurs, Hamburg 1985).

Shakespeare W., Romeo and Juliet, Penguin Books 1994.

Tischner J., Filozofia dramatu. Wprowadzenie, Kraków 1999.

Tischner J., Inny. Eseje o spotkaniu, Kraków 2017.

\section{Abstract \\ Another as the Other. Following the Dialogical Thought of Józef Tischner}

The world is a stage where everything is just a thing, even man. We discover it in an intentional opening. However, if we make a dialogical opening, man is no longer an object, but becomes a subject. Here we meet man as The Other and not as Another, an alien. Where do we encounter him? On the road, at the inn. What is needed? Setting a primal distance and entering into relation, in Martin Buber's terms, or a dialogical opening and 
personification, entering into language or speech, according to Józef Tischner. On the road, at the inn where everyone is another, an alien, we become the other.

\section{Keywords}

Another, The Other, relation, person, dialogical thought, Tischner 